\title{
Does strong governance stimulate the effect of economic freedom and financial literacy on financial inclusion? a cross-country evidence
}

\author{
Muhammad Hussain ${ }^{1}$, Farzan Yahya ${ }^{1 *}$ (1) and Muhammad Waqas ${ }^{2}$
}

\begin{abstract}
This study examines the interlinkages between financial literacy, economic freedom, government quality, and financial inclusion using cross-sectional and panel data analysis. Using a sample of 98 countries from the year 2007 to 2018, OLS and system GMM estimators were used to analyze the results. The estimation results indicate that financial literacy and government quality positively influence financial inclusion. Results also find that governance quality strengthens the effect of financial literacy on financial inclusion. The results derived from the dynamic panel model also reasonably conclude the positive effect of economic freedom on financial inclusion while government quality acts as a catalyst for their link. Our results are also robust to sub-panels based on the level of country risk.
\end{abstract}

Keywords: Financial inclusion, Economic freedom, Financial literacy, Governance quality

\section{Introduction}

Financial inclusion strategies may facilitate economies to achieve the United Nation's (UN) sustainable development goals (SDGs-2030). A strand of existing literature advocates that financial inclusiveness could mitigate the detrimental effects of poverty alleviation, income inequality, and financial instability in developing countries $[21,28,38,42,50,64]$. Although notable progress at the global level to increase account ownership ${ }^{1}$ is made, still a large population is financially excluded [32], and regional disparity in inclusive development $[25,26]$.

At a macro-level, financial inclusion is associated with accessibility, availability, and usage, but an individual can be considered as financially included who has a basic bank account with a formal financial institution [66]. The bank account holder is more likely to start savings, credit, insurance, and investment activity. Nevertheless, unfavorable regulatory systems are also restricting people to borrow, deposit, or use financial services more frequently. Institutional weakness, lack of financial literacy, and poor business operating environment can influence financial inclusiveness [1].

Excessive restrictions on economic activity distort the business operating environment and impede financial access [8]. Economic freedom acts as an engine to boost income growth and enhances savings in formal financial institutions $[4,66]$. The free economic conditions give rise to the competition which provokes financial institutions to develop more efficient financial inclusion strategies [40,54]. Even so, a conducive economic environment calls for the involvement of a financially literate society.

Financially illiterate people fail to manage their debts, investments, savings and generally make irrational decisions $[17,22,31]$. Financial literacy has a direct and significant impact on financial inclusion as it is responsible for the awareness of complex financial products, formal credit instruments, their access, and efficient utilization $[12,37,57]$.

*Correspondence: farzan.yahya@yahoo.com

${ }^{1}$ Institute of Southern Punjab, 9-KM, Bosan Road, Multan, Pakistan Full list of author information is available at the end of the article

\footnotetext{
1 The account ownership was $51 \%$ in year 2011, which increased to $67 \%$ in year 2017.
} 
Nonetheless, the association between economic freedom, financial literacy, government quality, and financial inclusion is not straightforward. Literacy and freedom are the important elements for society, but their growth can be impeded without the intervention of the state [14]. Banking efficiency is higher in the countries where government formulates and implements sound policies, higher quality governance, and higher economic freedom [16]. It is the responsibility of governmental institutions to ensure that banks should be regulated and supervised not only to protect investors and consumers but also to safeguard the soundness of the financial system $[10,16]$.

The first objective of the study is to investigate the effect of financial literacy on financial inclusion along with the moderating role of government quality. Although the link between financial literacy and financial inclusion is established by Grohmann et al. [22], it is not clear whether the link is intervened by institutional or governmental factors. The cross-country evidence of Grohmann et al. [22] illustrates that the informed customers (with higher financial literacy) make more rational decisions for their personal and business investment which supports the financial system efficiency and financial inclusion as a whole. Nonetheless, we believe that the effect of financial literacy can be expedited with the support of the government. For instance, the efficient government may promote numerical, technological, and scientific education at the primary level that may strengthen the link between financial literacy and financial inclusion. Owing to the declining tax base and increasing aging population at the global level, more capable governments design sound financial literacy policies to decrease the reliance on social security in retirement [18]. Thus, we also examine whether government quality influences financial inclusion through financial literacy. Testing the mediating effect of financial literacy on the relationship between government quality and financial inclusion will expand our lens to theoretical and empirical insights.

The second objective of the study is to examine the moderating effect of government quality on the relationship between economic freedom and financial inclusion. Studies argued that a higher level of economic freedom coupled with less stringent regulations may less likely to face financial crisis or turbulence [8,23]. At the macro-level, economic freedom improves sovereign credit ratings while leads to efficient credit allocation at the micro-level [59]. Although studies have developed the link of economic freedom with financial development and economic growth $[2,23]$, there is a dearth of empirical evidence related to its influence on financial inclusion. Since economic freedom accelerates technological diffusion and competition among financial institutions $[33,60]$, banks may thrive to promote more financial inclusive strategies. Nevertheless, even after limiting the degree of interventionism in the form of government ownership, regulations, and taxes, financial institutions may not be able to create incentives for financial inclusion in the presence of weak regulatory policies and political instability [15]. Therefore, a higher degree of government quality is important to strengthen the link between economic freedom and financial inclusion.

This study contributes to the existing financial inclusion literature. First, by extending the cross-country evidence of Grohmann et al. [22], we introduced the moderating role of government quality on the relationship between financial literacy and financial inclusion, which is previously overlooked. Second, we provide the first empirical evidence that estimates the mediating effect of financial literacy between these two variables. Third, compared to Grohmann et al. [22], we have used a more comprehensive composite index based on several financial inclusion proxies. This composite index is utilized by previous studies but not in the same empirical setting $[34,46]$. Fourth, to our best knowledge, prior studies have not specifically examined economic freedom with financial inclusion along with the moderating role of government quality at the global level. Lastly, in order to mitigate the endogeneity bias (possibly emerge from reverse causality and omitted variables bias), we utilized system GMM (sys-GMM) which is also a novel contribution of this study.

Our study proceeds with four sections after the introduction. In "Literature review" Section, we have discussed existing literature on financial inclusion, financial literacy, economic freedom, and government quality. "Methods" Section is related to the methodology, source of data collection, measurement of the variables, empirical model, and choice of statistical technique. "Results" Section consists of analysis and discussion. In the last section, the conclusion, policy implications, and directions for future research are discussed.

\section{Literature review}

An emerging strand of literature has studied the determinants of financial inclusion mainly in African countries, Chinoda and Kwenda [15], the SAARC region, Lenka and Barik [35], Muslim countries, Zulkhibri and Ghazal [67], and BRICS countries [43]. Almost all developing countries are struggling to design sophisticated financial inclusion strategies in order to increase the number of banked people and bringing their savings and investments to formal financial institutions [65]. However, certain challenges such as poverty, income inequality, low level of education, corruption, political and economic instability may impede the financial access and financial infrastructure [21, 38, 42, 51, [64].

Financial inclusion provides financial security to households, enhances the savings of individuals, and eventually leads to sustainable growth [21, 38, 42, 64]. To make 
financial products and services affordable and accessible to adults, awareness of financial products, less restricted economic situation, and higher quality of government could play an important role in bringing the vulnerable society to the mainstream formal banking system. Regulatory frameworks and effective enforcement are necessary to promote market development and competition as they restore consumer confidence and trust in banks which influence financial access [28]. In the absence of a strong rule of law, government effectiveness, regulatory quality, political stability, and accountability, financial transactions cannot be performed coherently [53, 67]. Thus, Pandya [49] argued that financial inclusion is less of a financial issue compared to a governance issue.

Anthony-Orji, Orji, Ogbuabor, and Nwosu [7] investigated the relationships among financial inclusion, financial stability, and institutional quality in Nigeria over the period 1986 to 2013. After analyzing the results through the autoregressive distributed lag model, they found that the impact of institutional quality is positive on financial inclusion in the long and short run. Zulkhibri and Ghazal [67] studied the determinants of financial inclusion in 69 Muslim and developing economies and suggested that governance followed by economic freedom influence the financial inclusion by increasing numbers of bank account and savings in formal financial institutions. Nonetheless, their results were inconclusive and mixed which calls for further empirical testing. Similarly, after applying system GMM on the panel data of 49 African countries, Chinoda and Kwenda [15] found that institutional quality and economic freedom positively influence financial inclusion. Mavrakana and Psillaki [40] argued that a high degree of economic freedom has a significant impact on bank performance and the soundness of the financial system.

According to Pham et al. [54], a higher rate of economic freedom is not only beneficial for promoting competition in the banking sector but also mitigates the detrimental effects of financial crises. Economic freedom indicators such as property rights, contract enforcement, and investment freedom increase foreign direct investment (FDI) activities in the country [13]. Consistent with prior studies, we argue that combine efforts of governance quality and economic freedom could transfer the unbanked population to formal financial institutions [8, 16, 53].

Besides economic freedom and governance quality, financial literacy is also an efficient mechanism to promote financial inclusion. Financial literacy helps acquire financial knowledge and concepts, risk management, business plan, and decision making about the financial products and services available in the financial markets. Lusardi [36] surveyed financial literacy in 15 countries by asking questions related to interest, inflation, and risk. Results show that financial literacy is low, even in the world's most developed financial markets. Rodrigues et al. [57] have conducted a quiz game to measure 1597 bank clients to judge the basic and advanced skills of financial literacy. It was found that basic financial literacy level was satisfactory, whereas there were serious concerns on advanced financial skills level. Bire et al. [12] revealed that the influence of financial literacy on financial inclusion is mediated by financial training in Indonesia. On the other hand, Grohmann et al. [22] investigated the heterogeneous effect of financial literacy on financial inclusion at the cross-country level by using instrumental variables (IV) regression analysis. They argued that financial literacy is important for access to finance and financial depth.

Lyons and Kass-Hanna [39] investigated the impact of financial literacy on financial inclusion in an economically vulnerable population of 13 MENA countries. Using probit regression analysis, they found that vulnerable groups-women, youth, less educated, and poor-were significantly less likely to be financially included. The financially illiterate population is using informal sources and other social networks for borrowings to meet emergency needs. However, households of countries with a higher level of financial literacy are more engaged in approaching formal financial sources for savings as well as borrowings. Similarly, [24] employed log-log, probit, and logistic regression models to investigate the effect of financial knowledge on financial inclusion in rural areas of Bangladesh. They argued that financial literacy can significantly remove the hurdles that restrict individuals to choose formal financial services. The results of Lyons and Kass-Hanna [39] also show that political stability and stronger legal rights are essential to facilitate financial literacy that may ultimately improve the financial behavior of households. Since complex financial instruments are introduced and financial markets are getting more unpredictable, a well-informed individual can make a good financial decision in the current era of globalization.

\section{Methods \\ Data source and sample}

Financial inclusion is the dependent variable of this study and measured through a composite index based on ATMs, bank branches, deposit accounts with commercial banks, and borrowers from commercial banks per 100,000 adults. The data of financial inclusion proxies are retrieved from Financial Access Survey-IMF. On the other hand, economic freedom is measured through an index compiled by the Fraser Institute. Although an index for economic freedom is also compiled by Heritage Foundation, Fraser Institute's index is widely used in previous studies. There are five items in the index, i.e., regulation, 
freedom to trade internationally, sound money supply, legal system and property rights, and size of government. These components have covered most aspects that may motivate the general population to move their savings to formal financial institutions. A wide range of studies have utilized this index to measure economic freedom (M. R. $[29,55,61]$

The data related to governance quality are collected from the World Governance Indicators (WGIs). The WGI has provided six individual and aggregate dimensions of governance including voice and accountability, political stability and absence of violence, government effectiveness, regulatory quality, rule of law, and control of corruption. Since some studies found mixed evidence for the individual dimensions, we used an aggregate measure of governance quality developed through principal component analysis (PCA) to eliminate the ambiguity. This process is used and justified by previous studies $[6,63]$

Financial literacy is measured through the data provided by a survey of Gallup in collaboration with the Global Financial Literacy Center and the World Bank. The survey was conducted in 143 countries in the year 2014. The five survey items were related to interest compounding, interest rate, inflation, and risk diversification. The same data and measurement were used by Grohmann et al. [22] in their study. Since the time-series data for financial literacy are not available, we relied on the cross-sectional analysis to estimate the financial literacy model with 111 countries. On the other hand, we employed panel data composed of 98 countries from the year 2007 to 2018 (after eliminating missing data) for the economic freedom model. We control for gross domestic product (GDP) growth and inflation. Studies revealed that economic growth is positively associated with financial inclusion $[7,22]$. However, inflation leads to income inequality and negatively influences saving behavior, which hinders financial inclusion [44]. Studies reveal that countries with high inflation experience low financial inclusion [5, 47]. The data related to control variables are retrieved from the World Bank database.

\section{Principal component analysis (PCA)}

Principal component analysis (PCA) is a dimensionality-reduction method used to transform large datasets into smaller ones without losing important information. Accordingly, we used PCA to develop the composite index of financial inclusion (FINDEX) and government of quality (GINDEX). By using PCA method, the $j^{\text {th }}$ factor index can be written as:

$$
\begin{aligned}
\operatorname{FINDEX}_{j}= & \operatorname{InW}_{J 1} X_{1}+\operatorname{InW}_{J 2} X_{2} \\
& +\operatorname{InW}_{J 3} X_{3}+\cdots+\operatorname{InW}_{J P} X_{P}
\end{aligned}
$$

$$
\begin{aligned}
\operatorname{GINDEX}_{j}= & \operatorname{InW}_{J 1} X_{1}+\operatorname{InW}_{J 2} X_{2} \\
& +\operatorname{InW}_{J 3} X_{3}+\cdots+\operatorname{InW}_{J P} X_{P}
\end{aligned}
$$

whereas FINDEX $_{\mathrm{j}}$ and GINDEX $_{\mathrm{j}}$ are financial inclusion index and governance index, respectively; $W_{\mathrm{j}}$ is the factor score weight of the parameter; $X$ is the initial value. The FINDEX is developed from the four factors, while GINDEX is developed from six factors of governance indicators. For measuring the sample adequacy, KaiserMeyer-Olkin (KMO) and the Bartlett test of sphericity are used. ${ }^{2}$ The value of KMO for FINDEX and GINDEX was 0.71 and 0.74 , respectively, along with significant Bartlett test values, which are considered in an acceptable (middling) range (H. F. [30].

\section{Empirical model}

Since the data on financial literacy are available for the only year (i.e., 2014), we used simple OLS regression (with robust standard errors) to estimate the effect of financial literacy on financial inclusion along with the moderating role of government quality. Owing to the fact that we are also estimating the mediating role of financial literacy on the relationship between government quality and financial inclusion, the procedure of Baron and Kenny [9] is employed:

$$
\begin{aligned}
& \text { FINDEX }=\beta_{1} \text { GINDEX }+\beta_{2} X+u \\
& \text { FL }=\beta_{1} \text { GINDEX }+\beta_{2} X+u \\
& \text { FINDEX }=\beta_{1} \text { GINDEX }+\beta_{2} \text { FL }+\beta_{3} X+u
\end{aligned}
$$

The OLS regression for the moderating role of government quality takes the following form:

$$
\begin{aligned}
\text { FINDEX }= & \beta_{1} \mathrm{FL}+\beta_{2} \text { GINDEX } \\
& +\beta_{3}(\mathrm{GINDEX} \times \mathrm{FL})+\beta_{4} X+u
\end{aligned}
$$

where FINDEX is the financial inclusion, GINDEX is the government quality, FL is the level of financial literacy, $\mathrm{X}$ is a matrix of control variables. However, to estimate the effect of economic freedom on financial inclusion along with the moderating role of government quality, the following OLS model is developed:

\footnotetext{
${ }^{2}$ Different techniques of normalization are used for robustness of results including $\mathrm{z}$-score, min-max, and soft max techniques. Technical details related to PCA and normalization are followed from the work of Abdi and Williams (2010). For the purpose of brevity, the results are not shown but can be provided on demand.
} 
Table 1 Descriptive statistics and correlation matrix (panel data and cross-sectional data)

\begin{tabular}{|c|c|c|c|c|c|c|c|c|}
\hline & Mean & S.D & FINDEX & GINDEX & EF & GDP & Inflation & VIF \\
\hline \multicolumn{9}{|c|}{ Panel data (the year 2007-2018) } \\
\hline FINDEX & -0.124 & 0.409 & 1 & & & & & \\
\hline GINDEX & -0.029 & 0.987 & $.320^{* *}$ & 1 & & & & 3.673 \\
\hline$E F$ & 63.692 & 8.730 & $.316^{* *}$ & $.837^{* *}$ & 1 & & & 3.375 \\
\hline GDP & 1.818 & 3.457 & $-.078^{* *}$ & $-.145^{* *}$ & $-.098^{* *}$ & 1 & & 1.026 \\
\hline Inflation & 4.493 & 5.154 & $-.233^{* *}$ & $-.451^{* *}$ & $-.416^{* *}$ & -0.018 & 1 & 1.338 \\
\hline \multicolumn{9}{|c|}{ Cross-sectional data (year 2014) } \\
\hline FINDEX & -0.146 & 0.337 & 1 & & & & & \\
\hline GINDEX & -0.124 & 0.899 & $.570^{* *}$ & 1 & & & & 2.226 \\
\hline $\mathrm{FL}$ & 34.775 & 12.105 & $.310^{* *}$ & $.712^{* *}$ & 1 & & & 2.092 \\
\hline GDP & 2.149 & 2.158 & -.044 & .120 & .012 & 1 & & 1.096 \\
\hline Inflation & 4.326 & 7.294 & -.177 & $-.373^{* *}$ & $-.261^{* *}$ & $-.268^{* *}$ & 1 & 1.277 \\
\hline
\end{tabular}

$$
\begin{aligned}
\text { FINDEX }= & \beta_{1} \mathrm{EF}+\beta_{2} \mathrm{GINDEX} \\
& +\beta_{3}(\mathrm{GINDEX} \times \mathrm{EF})+\beta_{4} X+u
\end{aligned}
$$

where EF is economic freedom. Although we begin our analysis with OLS estimations, we posit that the association between financial inclusion, economic freedom, and government quality is not unidirectional and could include endogeneity bias (omitted variable bias and reverse causality). Financial inclusion implies that the general public especially adult members of society should have access to financial products and services at affordable costs. For the reason that financial inclusion is strongly correlated with saving behavior and accessing credit from the formal financial institution, financially inclusive individuals demand a higher level of economic liberty, better regulatory quality, less information asymmetry, and strong investor protection policies [15, 43]. Therefore, financial inclusion may also lead to economic freedom and a higher degree of government quality.

Although fixed-effect estimations in panel data can eliminate the first source of endogeneity, i.e., omitted variable bias, however, it is not an efficient tool for resolving the reverse causality issue. Accordingly, we have utilized the generalized method of moment (GMM) with lagged values of independent variables as instruments to deal with both types of endogeneity. Since we are using a short panel $(N>T)$, the system GMM model is an appropriate instrument to mitigate the correlation between the error term and the endogenous variable. It also eliminates the autocorrelation of the error term [58]. Our dynamic panel data model has the following form:

$$
\begin{aligned}
\operatorname{FINDEX}_{i t}= & \alpha_{i t}+\beta_{1} \operatorname{FINDEX}_{i, t-1}+\beta_{2} \mathrm{EF}_{i, t} \\
& +\beta_{3} \operatorname{GINDEX}_{i t}+\beta_{4}(\operatorname{GINDEX} \times E F) \\
& +\beta_{5} X+\varepsilon_{i t}
\end{aligned}
$$

where $i$ is the cross-sectional unit (country), $\mathrm{t}$ stands for time-period, $X$ refers to control variables, country, and time effects, $\alpha$ is the unobserved fixed effect; and $\varepsilon$ are error terms being independently and identically distributed over the whole sample with constant variance. System GMM also assumes the stationarity of all variables due to which we estimated the panel unit root test ${ }^{3}$ of $\mathrm{Im}$, Pesaran, and Shin [27]. The results indicate the stationarity of all variables in level form.

\section{Results}

Descriptive statistics and correlation coefficients for panel data and cross-sectional data are given in Table 1. On average, there is a lower level of government quality and financial inclusion in the world. The average economic freedom is 63.692 with maximum economic freedom in Singapore and minimum in North Korea. Furthermore, the financial literacy of the world is 35 percent only, which should be improved for shifting unbanked individuals to formal financial institutions. Table 1 also shows that there is no multicollinearity ${ }^{4}$ issue among explanatory variables as all values of the Variance Inflation Factor are less than $5[3,42]$. The initial testing through correlation coefficient supports our hypothesis that government quality and economic freedom are positively associated with financial inclusion (Table 1). Similarly, the correlation of cross-sectional data analyzed in Table 1 also shows a positive association between financial literacy and financial inclusion.

\footnotetext{
${ }^{3}$ For the purpose of brevity, results are not reported in the paper. However the results of unit root test can be provided on demand.

4 These results also economic freedom and government quality are not highly linearly related and can be entered in the same model.
} 
Table 2 OLS estimations (cross-sectional data)

\begin{tabular}{|c|c|c|c|c|c|c|}
\hline \multirow[t]{2}{*}{ Variables } & \multicolumn{3}{|c|}{ DV = Fnancial literacy } & \multicolumn{3}{|c|}{ DV $=$ Fancial inclusion } \\
\hline & 1 & 2 & 3 & 4 & 5 & 6 \\
\hline \multirow[t]{2}{*}{ GDP } & -0.006 & -0.004 & 0.015 & 0.017 & 0.020 & 0.019 \\
\hline & $(0.007)$ & $(0.005)$ & $(0.150)$ & $(0.013)$ & $(0.013)$ & $(0.031)$ \\
\hline Inflation & $\begin{array}{l}-0.007^{* * *} \\
(0.002)\end{array}$ & $\begin{array}{r}-0.001 \\
(0.002)\end{array}$ & $\begin{array}{c}-0.009^{*} \\
(0.005)\end{array}$ & $\begin{array}{c}0.001 \\
(0.004)\end{array}$ & $\begin{array}{c}0.000 \\
(0.004)\end{array}$ & $\begin{array}{r}-0.001 \\
(0.004)\end{array}$ \\
\hline GINDEX & & $\begin{array}{l}0.117^{* * *} \\
(0.011)\end{array}$ & & $\begin{array}{l}0.220^{* * *} \\
(0.032)\end{array}$ & $\begin{array}{l}0.277^{* * *} \\
(0.043)\end{array}$ & $\begin{array}{l}0.273^{* * *} \\
(0.043)\end{array}$ \\
\hline $\mathrm{FL}$ & & & & & $\begin{array}{l}0.006^{* * *} \\
(0.003)\end{array}$ & $\begin{array}{l}0.007^{* * *} \\
(0.003)\end{array}$ \\
\hline GINDEX $\times$ FL & & & & & & $\begin{array}{l}0.049^{* * *} \\
(0.032)\end{array}$ \\
\hline Intercept & $\begin{array}{l}1.580^{* * *} \\
(0.023)\end{array}$ & $\begin{array}{l}1.550^{* * *} \\
(0.017)\end{array}$ & $\begin{array}{c}-0.072^{*} \\
(0.053)\end{array}$ & $\begin{array}{l}-0.083^{* * *} \\
(0.044)\end{array}$ & $\begin{array}{c}0.136 \\
(0.123)\end{array}$ & $\begin{array}{l}0.132^{* * *} \\
(0.122)\end{array}$ \\
\hline$R$-Squared & 0.085 & 0.510 & 0.040 & 0.337 & 0.360 & 0.374 \\
\hline
\end{tabular}

Note ${ }^{* * *}$, and ${ }^{* * *}$ indicate significance at the $10 \%, 5 \%$, and $1 \%$ levels, respectively

We start our analysis by examining the direct and indirect effects of financial literacy and government quality on financial inclusion (Table 2). The results of OLS estimations show that inflation is significantly and negatively associated with financial literacy $(\beta=0.01, p<0.1)$ as well as financial inclusion $(\beta=0.01, p<0.01)$. It can be purported that high inflation restricts individuals to use formal financial services due to lower levels of savings [47]. However, the effect turns insignificant when entered with the main variables of our interest. The effect of GDP on financial inclusion is insignificant in all models, implying that economic growth does not facilitate financial inclusiveness.

The effect of government quality is positive and significant on both financial literacy $(\beta=0.12, p<0.01)$ and financial inclusion $(\beta=0.22, p<0.01)$. Since the effect of government quality remains significant even after entering financial literacy in the model, we do not find that financial literacy fully mediates the relationship between government quality and financial inclusion. Nonetheless, we find a significant moderating effect of government quality on the relationship between financial literacy and financial inclusion $(\beta=0.10, p<0.01)$.

Likewise our financial literacy model, we begin our analysis with pooled OLS regression for our panel data model to examine the effect of economic freedom on financial inclusion along with the moderating role of governance quality. Table 3 shows that economic freedom is positively and significantly associated with financial inclusion in all models. The results of all models except the random effect estimator ${ }^{5}$ also show that

${ }^{5}$ Based on Hausman test, we find that fixed-effect estimations are more appropriate for our model compared to random effect estimations. government quality improves the financial inclusiveness in the country. Since the interaction of government quality and economic freedom is significant in all models except fixed-effect estimations, we believe that the combined effect of government quality and economic freedom may accelerate the transformation of the unbanked population to formal financial institutions. Owing to the upwardly biased results of pooled OLS and downwardly biased estimates for the fixed-effect estimator, we rely on the results of two-step system GMM estimations, which also account for endogeneity bias. The validity of instruments used by system GMM is tested through Hansen's J and Sargan statistics [11]. The insignificant values show that instruments are valid and not over-identified. Furthermore, this technique also eliminates the issue of serial correlation as Arellano-Bond's test for secondorder (AR2) is also insignificant.

\section{Robustness checks}

We divided our main panel into sub-panels based on country risk. ${ }^{6}$ Country risk is related to insecurities and lack of investor protection in a particular country. A higher level of country risk may reduce the access to finance and efficiency of the financial institution [19]. Based on Amfori country risk classification, we developed sub-panels of high-risk and low-risk countries. The results are slightly different for our sub-panels. In the presence of high-risk countries, we find that financial literacy influences financial inclusion through government quality. It is posited that informed individuals enforce governments to improve their effectiveness, regulatory

\footnotetext{
${ }^{6}$ List of high- and low-risk countries can be retrieved from amfori.org Results are available upon request.
} 
Table 3 Pooled OLS, fixed-effect, random-effect, and sys-GMM estimations (panel data)

\begin{tabular}{|c|c|c|c|c|}
\hline Variables & $\begin{array}{l}\text { Pooled OLS } \\
\text { model }\end{array}$ & $\begin{array}{l}\text { Random effect } \\
\text { model }\end{array}$ & Fixed effect model & SGMM model \\
\hline Lagged FINDEX & & & & $\begin{array}{l}0.064 \\
(0.019)\end{array}$ \\
\hline \multirow[t]{2}{*}{ GINDEX } & $0.053^{* * *}$ & 0.024 & $0.024^{* * *}$ & $0.103^{* * *}$ \\
\hline & $(0.022)$ & $(0.022)$ & $(0.022)$ & $(0.046)$ \\
\hline $\mathrm{EF}$ & $\begin{array}{l}0.007^{* * *} \\
(0.002)\end{array}$ & $\begin{array}{l}0.002^{* * *} \\
(0.001)\end{array}$ & $\begin{array}{l}0.002^{* * *} \\
(0.009)\end{array}$ & $\begin{array}{l}0.004^{* * *} \\
(0.004)\end{array}$ \\
\hline GINDEX*EF & $\begin{array}{l}0.014^{* * *} \\
(0.013)\end{array}$ & $\begin{array}{l}0.031^{* *} \\
(0.009)\end{array}$ & $\begin{array}{l}0.031 \\
(0.009)\end{array}$ & $\begin{array}{l}0.023^{* * *} \\
(0.025)\end{array}$ \\
\hline GDP & $\begin{array}{l}0.005 \\
(0.003)\end{array}$ & $\begin{array}{l}0.004 \\
(0.002)\end{array}$ & $\begin{array}{l}0.004 \\
(0.001)\end{array}$ & $\begin{array}{l}0.003 \\
(0.002)\end{array}$ \\
\hline INF & $\begin{array}{l}-0.009^{* * *} \\
(0.003)\end{array}$ & $\begin{array}{l}-0.005^{* * *} \\
(0.001)\end{array}$ & $\begin{array}{l}-0.005^{* * *} \\
(0.001)\end{array}$ & $\begin{array}{l}-0.005^{* * *} \\
(0.002)\end{array}$ \\
\hline$R^{2}$ & 0.348 & 0.966 & 0.090 & \\
\hline Intercept & $\begin{array}{l}-0.546^{* * *} \\
(0.155)\end{array}$ & $\begin{array}{l}-0.571^{* * *} \\
(0.078)\end{array}$ & $\begin{array}{l}-0.351 \\
(0.075)\end{array}$ & $\begin{array}{l}0.488^{* * *} \\
(0.264)\end{array}$ \\
\hline Year dummy & No & Yes & Yes & Yes \\
\hline Country dummy & No & Yes & Yes & Yes \\
\hline AR (1) 1st diff & & & & 0.000 \\
\hline AR (2) 1st diff & & & & 0.110 \\
\hline Sargan test & & & & 0.912 \\
\hline Hansen test & & & & 0.115 \\
\hline
\end{tabular}

Note The dependent variable is financial inclusion. Values in parenthesis are the estimated p-values. Hansen J-test refers to the over-identification test for the restrictions in GMM estimation. Wooldridge test for $A R(1)$ is the test of serial correlation for (the idiosyncratic component of) the errors. The AR2 test is the ArellanoBond test for the existence of the second-order autocorrelation in the first differences.

$*^{*}, *$, and ${ }^{* * *}$ indicate significance at the $10 \%, 5 \%$, and $1 \%$ levels, respectively

quality, and mitigate corruption so that their investments will be protected in the financial intermediaries. Results also show that the effect of economic freedom and government quality on financial inclusion is stronger in high-risk countries.

\section{Discussion}

Overall results show that strong governments and regulatory bodies develop supervisory and legal structures to support access to finance and financial inclusion strategies. Efficient governments generally do not face structural problems, which help them to effectively allocate resources. These results are in line with the study of Eldomiaty, Hammam, and El Bakry [20] that rule of law, regulatory quality, and political stability is essential to promote individuals' participation in the financial intermediaries. To facilitate financial inclusion, effective governments generate central information repositories related to financial service providers [45]. Our results are also consistent with the studies of Chinoda and Kwenda [15] and Zulkhibri and Ghazal [67] that government quality increases saving accounts by building trust among the general population.

Our cross-sectional evidence related to the effect of financial literacy on financial inclusion is consistent with the studies of Grohmann et al. [22] and Hasan et al. [24]. Financial education plays a vital role to equip individuals with information on savings and credit options. The basic concepts of finance encourage individuals to borrow and invest through the formal financial sector using sophisticated financial technologies [48, 62]. Likewise previous studies, we also postulate that financial literacy has a clear beneficial effect on the access to finance and use of financial services $[22,24]$. The significant moderating effect of government quality between financial literacy and financial inclusion also indicates that high institutional quality reduces involuntary financial exclusion by supporting financially literate individuals. Efficient governments may establish training programs aiming to improve numeracy, competency, and financial literacy to shift the unbanked population to formal financial institutions [20].

The results of panel data analysis show that economic freedom facilitates formal financial institutions by reducing uncertainties, deadweight loss, ineffectuality, promoting FDI, better legal environment, and intellectual right protection, leading to competitiveness and a favorable business environment [52]. In line with [56], we argue that economic freedom can improve the availability of credit information and foster financial access. We 
also found that the combined effect of effective governance and economic freedom accelerates the provision of financial services to the individuals. The inclusiveness of financial institutions can be stimulated with property rights, rule of law, free trade, and sound money supply, while sound governance including a transparent legal system and absence of corruption acts as a catalyst. To get through various stages of development successfully, countries should prioritize governance and economic freedom in their agenda [41].

\section{Conclusions}

This study has examined the relationship between financial literacy, economic freedom, the government of quality, and financial inclusion. Using cross-sectional and dynamic panel data evidence, we find a positive and significant effect of financial literacy and government quality on financial inclusion. Our results also show that government quality plays a vital role in strengthening the link between financial literacy and financial inclusion. In contrast to our propositions, we do not find any mediating effect of financial literacy between government quality and financial inclusion. Our panel data analysis shows that economic freedom is also significantly associated with financial inclusion. Additionally, free-market economies may more effectively shift their non-banked individuals to formal financial institutions in the presence of strong government regulations. Our empirical evidence indicates that economic freedom and government quality are mutually reinforcing and their ambidextrous performance enhances financial inclusion. Results of our subpanels show that financial literacy is an essential source of promoting government quality to improve financial inclusion in high-risk countries to protect their investments from expropriation.

From the policy recommendations' point of view, the complexity in documentation to open a bank account should be reduced. Contrary to establishing a physical branch, a bank agent model can be introduced to mobilize the savings of trusted investors and local retailers. It is the responsibility of the government to increase the accessibility of online communication networks, especially in rural areas of developing countries where financial literacy, as well as electronic banking systems, will be fortified. Additionally, governments should increase the disclosure and transparency of their policies to build investor's trust in the financial system of the country. The role of financial education and knowledge is very vigilant, especially in developing countries that enhance the accountability of financial institutions and regulatory bodies. Increasing government quality will not only improve customer protection, macroeconomic stability, and control corruption but also enable global regulatory standards related to capital adequacy, macro-prudential regulations, and dynamic provision, which facilitates the financial inclusiveness of an economy.

It should be noted that financial inclusion should be balanced at a level that should facilitate financial stability as dysregulations may create financial inefficiencies. Low-income customers may face high information and transaction costs, which enhance information asymmetries. Thus, financial regulation and government supervision in this regard are essential to reduce adverse selection or moral hazard issues that emerge from financial inclusion. To reduce corruption and information asymmetry issues in financial services, the digitalization of inclusive finance can play a very significant role in financial transformation [25].

Although we have controlled for certain macroeconomic variables in our models, there still exists an extensive difference among countries due to their government policies, income inequality level, interest rate, education, level of religiously, etc. which may influence the underlying relationships. Future studies should account for these factors to produce more robust estimates. Furthermore, we were able to obtain cross-sectional data for financial literacy, which may not provide micro-foundations for aggregate data analysis. This study has used a single composite measure for financial inclusion which may bring some statistical constraints. Future studies should employ multifactors of financial inclusion measures to estimate the multilateral financial inclusion level.

\section{Abbreviations \\ UN: United Nation; SDGs: Sustainable development goals; ATMs: Automatic teller machines; GMM: Generalized method of moments; SAARC: South Asian Association for Regional Cooperation; BRICS: Brazil, Russia, India, China, and South Africa; MENA: Middle East/North Africa; IMF: International Monetary Fund; WGI: Worldwide Governance Indicators; PCA: Principal component analysis; GDP: Gross domestic product; FINDEX: Financial inclusion index; GINDEX: Government of quality index.}

\section{Supplementary Information}

The online version contains supplementary material available at https://doi. org/10.1186/s43093-021-00090-9.

\section{Additional file 1}

Acknowledgements

We thank the editor and the anonymous reviewers for their constructive comments.

\section{Author's contributions}

$\mathrm{MH}$ collected the data, analyzed the results, and prepared the original draft. FY supervised $\mathrm{MH}$ in preparing the draft and developing the original draft, and helped in methodology as well as analysis. MW edited and reviewed the draft and made constructive changes to the draft. All authors have read and approved the manuscript. 


\section{Funding}

The authors received no specific funding.

\section{Availability of data and material}

We have used secondary sources to complete our study. No new data are used or produced in this study.

\section{Declarations}

\section{Competing interests}

The authors declare that they have no conflict of interest.

\section{Author details}

${ }^{1}$ Institute of Southern Punjab, 9-KM, Bosan Road, Multan, Pakistan. ${ }^{2}$ School of Management, Jiangsu University, 301 Xuefu Rd, Jingkou District, Zhenjiang, Jiangsu, China.

Received: 23 March 2021 Accepted: 27 July 2021

Published: 16 December 2021

\section{References}

1. Abubakar Yl, Mustapha RA, Ajiboye ES (2020) Impact of governance on financial development: evidence from West Africa. Hasanuddin Econom Bus Rev 3(3):103-111

2. Acikgoz B, Amoah A, Yılmazer M (2016) Economic freedom and growth: a panel cointegration approach. Panoeconomicus 63(5):541-562

3. Adkins $L$ (2010) Using Gretl for principles of econometrics (No. 1412). Oklahoma State University, Department of Economics and Legal Studies in Business

4. Akomolafe KJ, Danladi JD, Babalola O, Abah AG (2015) Monetary policy and commercial banks' performance in Nigeria. Public Policy Administrat Res 5(9):158-166

5. Allen F, Carletti E, Cull R, Qian JQ, Senbet L, Valenzuela P (2014) The African financial development and financial inclusion gaps. J Afr Econ 23(5):614-642

6. Aluko OA, Ibrahim M (2020) Institutions and the financial development-economic growth nexus in sub-Saharan Africa. Econom Notes 49(3):e12163

7. Anthony-Orji Ol, Orji A, Ogbuabor JE, Nwosu EO (2019) Do financial stability and institutional quality have impact on financial inclusion in developing economies? A new evidence from Nigeria. Int J Sustain Econom 11(1):18-40

8. Baier SL, Clance M, \& Dwyer GP (2012) Banking crises and economic freedom. Forthcoming in Economic Freedom of the World: 2012 Annual Report, edited by James Gwartney, Robert Lawson and Joshua Hall.

9. Baron RM, Kenny DA (1986) The moderator-mediator variable distinction in social psychological research: conceptual, strategic, and statistical considerations. J Pers Soc Psychol 51(6):1173

10. Barth JR, Caprio G, Levine R (2013) Bank regulation and supervision in 180 countries from 1999 to 2011. J Finan Econ Policy 5(2):111-219

11. Baum CF, Schaffer ME, Stillman S (2007) Enhanced routines for instrumental variables/generalized method of moments estimation and testing. Stand Genomic Sci 7(4):465-506

12. Bire AR, Sauw HM, Maria M (2019) The effect of financial literacy towards financial inclusion through financial training. Int J Soc Sci Humanit 3(1):186-192

13. Borojo DG, Yushi J (2020) The impacts of institutional quality and business environment on Chinese foreign direct investment flow to African countries. Econ Res Ekonomska Istraživanja 33(1):26-45

14. Carlsson F, Lundström S (2001) Political and economic freedom and the environment: the case of CO2 emissions. Goteborg University, Goteborg, Department of Economics

15. Chinoda T, Kwenda F (2019) The impact of institutional quality and governance on financial inclusion in Africa: a two-step system generalised method of moments approach. J Econ Finan Sci 12(1):9

16. Chortareas GE, Girardone C, Ventouri A (2013) Financial freedom and bank efficiency: evidence from the European Union. J Bank Finance 37(4):1223-1231
17. Cupak A, Fessler P, Silgoner M, \& Ulbrich E (2018) Exploring differences in financial literacy across countries: the role of individual characteristics and institutions. Oesterreichische Nationalbank Working Papers (Austria), 220, pp. 1-39.

18. Cupák A, Kolev Gl, Brokešová Z (2019) Financial literacy and voluntary savings for retirement: novel causal evidence. Eur J Finan 25(16):1606-1625

19. Deléchat C, Newiak M, Xu R, Yang F, Aslan G (2018) What is driving women's financial inclusion across countries? IMF Working Paper 18/38, Washington, DC, International Monetary Fund.

20. Eldomiaty T, Hammam R, El Bakry R (2020) Institutional determinants of financial inclusion: evidence from world economies. Int J Develop Issues 19(2):217-228. https://doi.org/10.1108/IJDI-08-2019-0147

21. Frączek B (2019) relationships between financial inclusion and financial stability and economic growth-the opportunity or threat for monetary policy? Multiple Perspectives in Risk and Risk Management. Springer, Berlin, pp 261-278

22. Grohmann A, Klühs T, Menkhoff L (2018) Does financial literacy improve financial inclusion? Cross country evidence. World Dev 111:84-96

23. Hafer RW (2013) Economic freedom and financial development: international evidence. Cato J 33:111

24. Hasan M, Le T, Hoque A (2021) How does financial literacy impact on inclusive finance? Finan Innov 7(1):1-23

25. Hasan MM, Yajuan L \& Khan S (2020) Promoting China's inclusive finance through digital financial services. Global Bus Rev, 0972150919895348

26. Hasan MM, Yajuan L, Mahmud A (2020) Regional development of China's inclusive finance through financial technology. SAGE Open 10(1):2158244019901252

27. Im KS, Pesaran MH, Shin Y (2003) Testing for unit roots in heterogeneous panels. J Econometr 115(1):53-74

28. Islam ME (2016) Financial inclusion in Asia and the Pacific. In: Paper presented at the the First High-Level Follow-up Dialogue on Financing for Development in Asia and the Pacific Conference. UNESCAP, Korea, 2016.

29. Islam MR (2018) Wealth inequality, democracy and economic freedom. J Comp Econ 46(4):920-935

30. Kaiser HF (1974) An index of factorial simplicity. Psychometrika 39(1):31-36

31. Kaiser T, Menkhoff $L$ (2017) Does financial education impact financial literacy and financial behavior, and if so, when? World Bank Econ Rev 31(3):611-630

32. Koomson I, Villano RA, Hadley D (2020) Intensifying financial inclusion through the provision of financial literacy training: a gendered perspective. Appl Econ 52(4):375-387

33. Kouton J, Bétila RR, \& Lawin M (2020). The Impact of ICT Development on Health Outcomes in Africa: Does Economic Freedom Matter? J Knowl Econ, pp. 1-40.

34. Le T-H, Chuc AT, Taghizadeh-Hesary F (2019) Financial inclusion and its impact on financial efficiency and sustainability: Empirical evidence from Asia. Borsa Istanbul Rev 19(4):310-322

35. Lenka SK, Barik R (2018) Has expansion of mobile phone and internet use spurred financial inclusion in the SAARC countries? Finan Innov 4(1):1-19

36. Lusardi A (2019) Financial literacy and the need for financial education: evidence and implications. Swiss J Econ Stat 155(1):1-8

37. Lyons AC, Grable J, Zeng T (2019) Impacts of financial literacy on the loan decisions of financially excluded households in the People's Republic of China (February 20, 2019). ADBI Working Paper 923

38. Lyons AC, Grable JE, Joo S-H (2018) A cross-country analysis of population aging and financial security. J Econom Age 12:96-117

39. Lyons AC, Kass-Hanna J (2019) Financial inclusion, financial literacy and economically vulnerable populations in the Middle East and North Africa. Emerg Markets Finance and Trade 57(9):2699-2738

40. Mavrakana C \& Psillaki M (2019) Do economic freedom and board struc ture matter for bank stability and bank performance? MPRA Paper No. 95709

41. Medina-Moral E, Montes-Gan VJ (2018) Economic freedom, good governance and the dynamics of development. J Appl Econ 21(1):44-66

42. Michael $O B$, Sharon $O O$ (2014) Financial system, financial inclusion and economic development in Nigeria. Int J Manag Sci 2(3):139-148

43. Nagpal A, Jain M, Jain A (2020) Determining the role of digital technology, governance and institutions in advancing financial inclusion in 
BRICS nations using probit regression analysis. J Soc Econ Develop 22(2):443-459

44. Neaime S, Gaysset I (2018) Financial inclusion and stability in MENA evidence from poverty and inequality. Financ Res Lett 24:230-237

45. Bongomin GOC, Ntayi JM, Munene JC, Nabeta IN (2016) Social capital: mediator of financial literacy and financial inclusion in rural Uganda. Rev Int Bus Strat 26(2):291-312. https://doi.org/10.1108/RIBS-06-2014-0072

46. Omar MA, Inaba K (2020) Does financial inclusion reduce poverty and income inequality in developing countries? A panel data analysis. J Econom Struct 9:1-25

47. Omar MA, Inaba K (2020) Does financial inclusion reduce poverty and income inequality in developing countries? A panel data analysis. J Econom Struct 9(1):1-25

48. Ozili, PK (2020) Financial inclusion research around the world: A review. In Forum for social economics. Routledge, pp 1-23

49. Pandya R (2010) Speeding Financial Inclusion. Indian Journal of Agricultural Economics 65(4):797

50. Park C-M (2017) Quality of governance and regime support: Evidence from East Asia. Asian J Comparat Polit 2(2):154-175

51. Park CY, Mercado R Jr (2018) Financial inclusion, poverty, and income inequality. Singapore Econ Rev 63(01):185-206

52. Pearson D, Nyonna D, Kim K-J (2012) The relationship between economic freedom, state growth and foreign direct investment in US states. Int J Econ Financ 4(10):140-146

53. Pérez-Cárceles MC, Gómez-García J, Gallego JCG (2019) Goodness of governance effect on European banking efficiency. Int Rev Econ Financ 64:29-40

54. Pham TTT, Nguyen TVH, Nguyen K (2019) Does bank competition promote financial inclusion? A Cross-Country Evid Appl Econ Lett 26(13):1133-1137

55. Ram R (2014) Measuring economic freedom: a comparison of two major sources. Appl Econ Lett 21(12):852-856

56. Rekha G, Rajamani K, \& Resmi G (2021) Digital Financial Inclusion, Economic Freedom, Financial Development, and Growth: Implications from a Panel Data Analysis ADBI Working Paper Series: Asian Development Bank Institute.
57. Rodrigues LF, Oliveira A, Rodrigues H, Costa CJ (2019) Assessing consumer literacy on financial complex products. J Behav Exp Financ 22:93-104

58. Roodman D (2009) How to do xtabond2: an introduction to difference and system GMM in Stata. Stand Genomic Sci 9(1):86-136

59. Roychoudhury S, Lawson RA (2010) Economic freedom and sovereign credit ratings and default risk. J Finan Econ Policy 2(2):149-162

60. Sarpong-Kumankoma E, Abor JY, Aboagye AQ, \& Amidu M (2020) Economic freedom, competition and bank stability in Sub-Saharan Africa. Int J Product Perform Manage

61. Sharma A (2020) Does economic freedom improve health outcomes in sub-Saharan Africa? Int J Soc Econ 47(12):1633-1649. https://doi.org/10 1108/IJSE-01-2020-0008

62. Shen Y, Hueng CJ, Hu W (2020) Using digital technology to improve financial inclusion in China. Appl Econ Lett 27(1):30-34

63. Venger O, Miethe TD (2018) Volatile places, volatile times: Predicting revolutionary situations with nations' governance and fragility indicators. Soc Indic Res 138(1):373-402

64. VO AT, Van LTH, VO DH, McAleer M (2019) Financial inclusion and macroeconomic stability in emerging and frontier markets. Ann Finan Econ 14(02):1950008

65. Yin X, Xu X, Chen Q, Peng J (2019) The sustainable development of financial inclusion: how can monetary policy and economic fundamental interact with it effectively? Sustainability 11(9):2524

66. Zins A, Weill $L$ (2016) The determinants of financial inclusion in Africa. Rev Dev Finance 6(1):46-57

67. Zulkhibri M, Ghazal R (2017) The impacts of governance and institution on financial inclusion: Evidence from Muslim countries and developing economies. J King Abdulaziz Univer Islamic Econ 30:37-60

\section{Publisher's Note}

Springer Nature remains neutral with regard to jurisdictional claims in published maps and institutional affiliations.

\section{Submit your manuscript to a SpringerOpen ${ }^{\circ}$ journal and benefit from:}

- Convenient online submission

- Rigorous peer review

- Open access: articles freely available online

- High visibility within the field

- Retaining the copyright to your article

Submit your next manuscript at $\boldsymbol{\nabla}$ springeropen.com 